\title{
AGAMA DAN BUDAYA MALU SEBAGAI KONTROL SOSIAL TERHADAP PERILAKU KORUPTIF
}

\author{
Khodijah \\ Fakultas Ushuluddin dan Filsafat, UIN Sunan Ampel Surabaya \\ khodijah@gmail.com
}

\begin{abstract}
Abstrak
Korupsi di Indonesia selalu ada setiap tabunnya, hal ini menunjukekan bahwa masib belum terciptanya kontrol sosial yang optimal untuk menanggulangi permasalahan korupsi. Peneliti memiliki pertanyaan besar bagaimana jika untuk meningkatkan kontrol sosial dalam rangka menangani perilaku koruptif menggunakan budaya malu dan pedoman agama sebagai sarananya. Metode penelitian ini adalah library research dengan menggunakan pendekatan kualitatif. Peneliti memilib metode ini karena penelitian ini membutubkan banyak sumber data penelitian terdabulu dan juga membutubkan perbandingan dengan penelitian sebelumnya terkait dengan budaya malu dan pedoman agama yang dikombinasikan untuk meningkatkan kontrol sosial sebagai sarana menanggulangi perilaku koruptif. Penelitian ini menggunakan teori dari Travis Hirschi terkait dengan kontrol sosial. Hasil penelitian menunjukekan bahwa budaya malu dan pemahaman serta pengamalan beragama di Indonesia masih sangat lemah dan belum mampu untuk. memberikan efek jera pada pelaku korupsi.
\end{abstract}

Kata Kunci: Budaya Malu, Agama, Pengendalian Diri, Rasa Malu, Kontrol Sosial

\begin{abstract}
Corruption in Indonesia always exists every year, this shows that there is still no optimal social control to overcome corruption problems. Researchers have a big question what if to improve social control in order to deal with corrupt behavior using a culture of shame and religious guidelines as a means. This research method is a library research using a qualitative approach. Researchers chose this method because this research requires many sources of previous research data and also requires comparison with previous research related to the culture of shame and religious guidelines that are combined to improve social control as a means of overcoming corrupt behavior. This study uses the theory of Travis Hirschi related to social control. The results of this study show that the culture of shame and understanding and practice of religion in Indonesia are still very weak and have not been able to provide a deterrent effect on perpetrators of corruption.
\end{abstract}

Keywords: Culture of Shame, Religion, Self-Control, Shame, Social Control

\section{PENDAHULUAN}

Permasalahan Korupsi bukanlah hal yang baru ada di Indonesia dan telah menjadi topik yang selalu diperbincangkan hingga saat ini bahkan 52\% masyarakat Indonesia selalu update dengan permasalahan korupsi, terlebih tiap kasus korupsi yang terjadi selalu dialami oleh pejabat publik, tokoh politik, ketua dalam suatu partai, dan lain sebagainya1. Maraknya kasus korupsi tentunya membuat masyarakat dirugikan, bagaimana tidak? Uang yang seharusnya diperuntukkan rakyat dan dipercayakan oleh rakyat justru digunakan untuk keperluan pribadi. (Jawa Pos, Desember 2018)

Data yang dibuat oleh KPK dari tahun ke tahun memang menunjukkan bahwa selalu terjadi perilaku koruptif secara langsung maupun tidak langsung, dan hal yang mengejutkan adalah lebih dari $50 \%$ pelaku memiliki status dan jabatan sebagai orang yang telah dipilih dan dipercayai oleh rakyat (KPK.go.id) Menurut Ko \& Moon (2013), terdapat kaitan yang kuat antara perilaku koruptif dengan agama, dan didalam jurnalnya dikatakan bahwa pedoman dan peranan agama sangat mempengaruhi attitude dan perilaku manusia, dengan adanya pedoman agama, nilai-nilai spiritual akan membantu 
Khodijah: Agama dan Budaya Malu Sebagai...

seseorang mengontrol diri untuk tidak melakukan perilaku koruptif karena muncul kesadaran diri akan tanggung jawab dan amanah yang telah diberikan.

Agama memiliki peranan yang penting terhadap spiritualitas seseorang, dengan adanya penanaman spiritualitas melalui agama, individu secara tidak langsung akan memahami makna dan norma sosial yang berlaku, hal ini terbukti ketika penelitian yang dilakukan oleh Leaman (2009) yang menunjukkan bahwa adanya hubungan antara tingkat spiritualitas seseorang, agama, dan korupsi, sehingga dapat dikatakan lemahnya spiritualitas individu dan kurangnya pedoman agama akan memunculkan resiko seseorang memiliki perilaku koruptif meskipun ia mengetahui bahwa hal tersebut bertentangan dengan norma sosial maupun agama.

Keseluruhan agama tentunya mengajarkan kebaikan bagi seluruh umatnya dan tidak ada agama satupun yang mengajarkan untuk menghancurkan umatnya sendiri untuk kepentingan pribadi, tak terkecuali juga agama islam, dimana nabi Muhammad SAW selalu mengajarkan pada umatnya untuk saling tolongmenolong, menghargai satu sama lain, dan menjaga amanah yang telah dipercayakan orang lain pada kita.

Peneliti memiliki asumsi bahwa pedoman agama ini penting menjadi salah satu sarana untuk meningkatkan kontrol sosial guna menanggulangi perilaku koruptif, namun perlu adanya tambahan untuk memperkuat agar perilaku koruptif tersebut tidak terjadi, yaitu dengan menegakkan budaya malu dalam diri individu. Mengapa hal tersebut menjadi salah satu faktor penting juga dalam penanggulangan perilaku koruptif dan meningkatkan kontrol sosial? Peneliti beranggapan bahwa budaya malu (shame culture) yang diterapkan akan membuat efek jera bagi kebanyakan orang yang memiliki perilaku koruptif, banyak macam yang bisa dilakukan untuk menerapkan budaya malu ini, sebagai contoh menggunakan pamflet atau slogan-slogan yang melabel bahwa "koruptor adalah musuh negara, koruptor adalah penghancur moral bangsa, koruptor adalah aib negara, dan lain sebagainya". Sebenarnya Indonesia telah menerapkan budaya ini sejak lama, karena pada dasarnya seseorang yang melakukan korupsi secara tidak langsungakan dikucilkan oleh masyarakat, dipandang buruk oleh masyarakat dan pastinya memunculkan rasa malu pada diri koruptor tersebut. Inilah yang bisa disebut dengan penerapan budaya malu secara tidak langsung. Adanya perasaan malu ini yang nantinya digunakan sebagai sarana untuk memperkuat kontrol sosial dalam masyarakat agar tidak terjadi perilaku koruptif untuk kedepannya.

Adanya budaya malu dan pedoman yang dimiliki individu hal ini akan menjadikan kontrol sosial lebih terakumulasi dan terfokus pada pemberantasan perilaku koruptif yang dimiliki individu. Menurut Hirschi (2010) sebagai tokoh pencetus teori kontrol sosial mengemukakan bahwa kontrol sosial dilakukan karena pada dasarnya manusia adalah makhluk yang memiliki moral yang bisa dikontrol tidak hanya dari diri individu itu sendiri tapi juga dari sosial dan lingkungan sekitarnya, hal tersebut juga termasuk lingkungan pertemanan, kerja, hingga lingkungan keluarga ikut berperan aktif dalam terbentuknya kontrol sosial. Berdasarkan fenomena-fenomena tentang perilaku koruptif inilah, peneliti ingin melihat efektivitas dan kebergunaan dari pedoman agama dan budaya malu sebagai sarana untuk menanggulangi perilaku koruptif yang ada di Indonesia, oleh karena itulah penelitian ini dilakukan untuk menjawab hal tersebut.

Penelitian yang dilakukan oleh Leaman (2009) menjelaskan bahwa agama dan spiritualtas menjadi penyebab penentu terjadinya korupsi sektor publik, disisi lain, korupsi sektor publik juga menjadi penyebab penentu dalam pertumbahan ekonomi dan standar hidup. Leaman juga berpendapat dalam penelitiannya bahwa agama dan spiritualitas memilikidampak yang positif untuk mengurangi tingkat perilaku koruptif yang terjadi tidak hanya pada satu negara, tapi juga negara-negara lain. Penelitian oleh Leaman (2009) membuktikan bahwa agama dan spiritualitas dapat mengurangi tingkat koruptif yang terjadi, inilah yang menjadi salah satu alasan juga dalam penelitian ini menggunakan pedoman agama yang nantinya dijadikan sebagai kontrol sosial untuk menanggulangi perilaku koruptif di Indonesia 
Penelitian dari Hutagalung (2007) juga mengungkapkan bahwa budaya malu, budaya salah juga ikut berperan penting dalam mengontrol perilaku seseorang, dengan adanya rasa malu dan rasa bersalah yang ada dalam diri individu, hal tersebut membuat seseorang tidak akan melakukan perilaku yang akan membuat dirinya merasa malu ataupun merasa bersalah, hal inilah juga yang menjadi faktor penting bagi peneliti untuk lebih menekankan kontrol sosial dalam masyarakat dengan media pedoman agama dan budaya malu sebagai sarana yang dilakukan untuk mencegah, mengurangi atau bahkan menghilangkan perilaku koruptif pada diri seseorang.

Berdasarkan penelitian-penelitian terdahulu, nampak bahwa penelitian selalu fokus terhadap kaitan antara perilaku korupsi dengan agama, spiritualitas, dan hukum yang berlaku pada tiap negara atau daerah yang ditinggali individu pelaku korupsi, dan belum ada penelitian yang lebih memfokuskan solusi untuk permasalahan tersebut, terlebih tentang kontrol sosial dalam masyarakat dengan cara memanfaatkan pedoman agama dan budaya malu sebagai solusi untuk menanggulangi tingkat perilaku koruptif yang sangat tinggi di Indonesia.

\section{METODE}

Penelitian ini menggunakan metode penelitian kualitatif yang bertujuan untuk memahami mengapa manusia melakukan suatu perilaku tertentu, bagaimana perilaku tersebut dalam sudut pandang individu, bagaimana perasaan individu ketika berperilaku tertentu, emosi apa yang mendasari individu melakukan perilaku tertentu, nilai-nilai apa yang mendasarinya, faktor apa yang menyebabkan individu melakukan perilaku tertentu tersebut, dan bagaimana dinamika antara faktor-faktor tersebut(Herdiansyah, 2015). Penelitian ini dilakukan dengan menggunakan pendekatan kualitatif dengan metode Library Research dimana semua data akan diambil dari penelitianpenelitian sebelumnya dan dari analisis teori untuk dikaitkan dengan kontrol sosial sebagai sarana penanggulangi perilaku koruptif yang ada di Indonesia. Metode ini dipilih karena keefektifitasan dari sebuah penelitian akan didapatkan dan juga pembahasan akan lebih mendalam terkait dengan pemanfaatan teori kontrol sosial.

\section{HASIL DAN PEMBAHASAN}

\section{Teori Kontrol Sosial Travis Hirschi}

Travis Hirschi (1969) dalam bukunya mengungkapkan bahwa perilaku yang terjadi dalam masyarakat terjadi karena adanya kegagalan sosialisasi pada masyarakat terkait dengan komitmen dan kesadaran tentang norma, aturan, dan tata tertib yang ada. Penyimpangan yang terjadi dan perilaku kriminalitas yang dilakukan oleh seseorang dianggap sebagai suatu dampak dari kegagalan masyarakat dan lingkungan sekitarnya dalam membentuk kontrol sosial, seperti keluarga, sekolah, dan lain sebagainya (Hirschi, 1969). Hirschi (1969) mengungkapkan bahwa manusia pada dasarnya adalah individu yang tidak bisa mentaati aturan dan hukum, oleh karena itulah diperlukan adanya kontrol sosial untuk menjadikan individu tersebut mau untuk mematuhi aturan yang ada dan ikut serta meningkatkan kontrol sosial dalam masyarakat. Penelitian ini akan mengangkat tema tentang perilaku koruptif yang ada di Indonesia, dan peneliti meyakini bahwa adanya kontrol sosial hal tersebut akan bisa menjadi sebuah cara yang praktis dimana kontrol sosial ini diperkuat dengan memanfaatkan pedoman agama dan budaya malu yang nanti akan dibahas.

Hirschi (1969) juga mengungkapkan bahwa terdapat 4 unsur yang membentuk kontrol sosial dalam suatu masyarakat lemah atau kuat, diantaranya: Attachment, Commitment, Involvement, dan believe.

a. Attachment

Unsur ini biasa disebut juga dengan kasih sayang, unsur kasih sayang yang dimiliki tiap individu akan secara tidak langsung akan membantu terbentuknya kontrol sosial yang optimal, karena unsur ini didapatkan dari sosialisasi dan ajaran dari kelompok primernya yaitu keluarga. Semua nilai, semua ajaran, dan semua pembentukan dimulai dari keluarga, itulah kenapa apabila terdapat unsur Attachment yang sangat baik maka kontrol sosial yang 
ingin dicapai-pun dapat menjadi lebih baik pula.

b. Commitment

Unsur yang tidak kalah penting dalam pembentukan kontrol sosial adalah komitmen. Komitmen yang dimaksudkan adalah adanya tanggung jawab pada tiap individu terkait dengan kesadaran akan pentingnya mentaati peraturan dan norma yang ada dalam masyarakat, dan dengan adanya komitmen tentang pentingnya kesadaran mentaati aturan inilah yang membuat individu akan selalu memiliki pola pikir bahwa perilaku menyimpang akan menimbulkan dampak negatif bagi dirinya.

c. Involvement

Keterlibatan dalam masyarakat juga merupakan unsur yang penting. Aturan yang berlaku, norma-norma dan nilai yang berlaku ditanamkan dalam masyarakat dan disetujui oleh masyarakat juga. Keterlibatan dan keikutsertaan masyarakat dalam menjaga dan menerapkan aturan-aturan juga akan menimbulkan pengaruh dalam hal mengajak, saling menjaga, dan saling mentaati aturan bagi tiap individunya, sehingga ketika banyak individu dalam satu kelompok atau masyarakat mentaati peraturan yang berlaku, hal tersebut juga akan membuat individu disekitarnya mentaati aturan yang ada. Itulah mengapa unsur ini begitu penting dalam membentuk kontrol social.

d. Believe

Unsur terakhir yang juga sangat penting adalah kepercayaan, keyakinan, dan kepatuhan terhadap aturan, norma, dan nilai yang ada. Penanaman belief pada individu akan membuat individu tersebut memiliki keyakinan bahwa untuk mentaati aturan adalah suatu kewajiban dan akan terjadi kesengsaraan apabila dia melanggar aturan-aturan tersebut.

Keempat unsur inilah yang apabila diperkuat akan menyebabkan munculnya kontrol sosial yang optimal, dan masyarakat tidak perlu khawatir karena dengan adanya kontrol sosial yang tinggi, angka perilaku kriminalitas bisa ditekan hingga titik terendahnya, untuk kasus apapun, tak terkecuali juga kasus korupsi, namun hal yang perlu diperhatikan adalah untuk mewujudkan keempat unsur ini diperlukan persiapan yang matang. Banyak cara yang bisa digunakan untuk memunculkan keempat unsur tersebut dan memperkuat kontrol sosial salah satunya dengan pedoman agama dan budaya malu.

\section{Pedoman Agama Sebagai Pengontrol Perilaku Manusia}

Pedoman agama dalam khazanahislam berarti sebuah ajaran, sebuah didikan, dan sebuah pegangan untuk manusia dalam menjalani kehidupannya (Muhammadin, 2013). Agama islam adalah agama yang paling dominan di Indonesia, dalam pembelajarannya, islam memiliki kaidahkaidah terkait dengan permasalahan korupsi, dan didalam islam, perilaku koruptif yang dimiliki manusia bertentangan dengan ajaran keadilan dalam islam (al-'adalah), akuntabilitas, serta tanggung jawab (al-amanah). Perilaku koruptif yang dilakukan, serta dampak yang terjadi dari perilaku koruptif tersebut akan berdampak negatif terhadap diri pelaku dan masyarakat, sehingga dapat dikatakan bahwa perbuatan korupsi ini termasuk perbuatan fasad yang berarti kerusakan, dan perbuatan inilah yang paling dibenci oleh Allah SW'T. Dalil-dalil yang dapat digunakan untuk memaknai hukum korupsi dalam islam adalah QS. Ali Imran [03] Ayat 161, hadits riwayat Abu Dawud dan Umar bin Khattab, hadits riwayat al - Bukhari dari abi Hamid al- Sa'idi, dan juga hadits riwayat Al Tirmidzi dari Abdullah bin Amar.

Dalil yang telah dicetuskan dalam ajaran islam memang tidak secara langsung membahas tentang korupsi, namun dalam prakteknya, dalil tersebut menjelaskan bahwa penyalahgunaan wewenang, kebijakan, kekuasaan, dan jabatan adalah perilaku yang sangat dilarang dalam islam, dan dari makna tersebut dapat dikatakan bahwa perilaku koruptif hukumnya haram dalam islam. Banyak ajaran dari agama islam yang menunjukkan bahwa kepercayaan dan amanah yang diberikan kepada individu harus benarbenar dijaga dan dalam QS al- Ma'arij ayat 8 dan 32 juga menjelaskan tentang pentingnya menjaga amanah yang telah diberikan, namun 
dalam konteksnya, perilaku koruptif justru melakukan hal yang bertentangan dengan penjagaan amanah, adanya pengkhianatan dan kelalaian dalam memelihara janji dan kepercayaan.

Berbicara soal perspektif Islam tentang korupsi, patut dirujuk pada al-Qur'an dan alHadits sebagai sumber utama dari ajaran Islam.Sebagai agama yang sempurna dan universal,Islam tidak hanya mengatur hubungan antaramakhluk dengan khalik (hablum minallah), tetapi juga mengatur hubungan antar sesama makhluk (hablum minannas), serta hubungan antara manusia dengan alam (hablum minal 'alam). Oleh karenaitu, Islam mengajarkan secara komprehensif beberapa prinsip agar hubungan antar manusiamenjadi harmonis dan beradab. Dalam bentuk lain, Islam juga mengembangkan bentuk peraturan dan perundangan yang tegas, sistem pengawasan administratif, dan managerial yang ketat. Oleh sebab itu, dalam memberikan dan menetapkanhukuman bagi pelaku korupsi seharusnya tidakpandang bulu, apakah ia seorang pejabat ataukahlainnya. Tujuan hukuman tersebut ialah memberikanrasa jera guna menghentikan kejahatan yang telah ialakukan, sehingga dapat diciptakan rasa damai danrukun di tengah-tengah masyarakat.

Terdapat banyak ungkapan yang dapat dipakai untuk menggambarkan pengertian korupsi, meskipun tidak seutuhnya benar. Akan tetapi tidak terlalu jauh dari hakikat dan pengertian korupsi itu sendiri. Ada sebagian yang menggunakan istilah "akhdul amwal bil bathil" (memakan harta orang lain dengan cara yang batil), sebagaimana disebutkan oleh al- Qura'n dalam surat al-Baqarah ayat 188: Artinya; Dan janganlah sebahagian kamumemakan harta sebahagian yang lain diantara kamu dengan cara yang batil dan (janganlah) kamu membawa (urusan) hartaitu kepada hakim, supaya kamu dapatmemakan sebahagian daripada harta bendaorang lain itu dengan (jalan berbuat) dosa,padahal kamu mengetahui. Selain itu, terdapat juga term alsuhtu yang bermakna "yang haram/alsuhtu/suap" dalam surat al-Maidah ayat 42: Artinya; Mereka itu adalah orang-orang yang suka mendengar berita bohong, banyak memakan yang haram. Jika mereka (orangYahudi) datang kepadamu (untuk meminta putusan), maka putuskanlah (perkara itu) diantara mereka, atau berpalinglah darimereka; jika kamu berpaling dari mereka,maka mereka tidak akan memberi mudarat kepadamu sedikitpun. Dan jika kamumemutuskan perkara mereka, maka putuskanlah (perkara itu) di antara mereka dengan adil, sesungguhnya Allah menyukai orang-orang yang adil.

Dari beberapa ayat al-Qur'an yang dikemukakan di atas diketahui bahwa terdapat tiga unsur korupsi; yaitu memperkaya diri sendiri atau orang lain, mengambil harta orang lain dengan jalan tidak sah (penyelewengan, penyalahgunaan kekuasaan), dan melawan hukum. Lebih jauh, Islam melalui kitab suci alQur'an telah memerintahkan kepada seluruh penganutnya untuk melaksanakan ajaran Islam secara keseluruhan. Sebagaimana dinyatakan dalam al- Qur'an surat al-Baqarah ayat 208: Artinya; Hai orang-orang yang beriman,masuklah kamu ke dalam Islam secara keseluruhan, dan janganlah kamu turuti langkah-langkah syaitan. Sesungguhnya syaitan itu musuh yang nyata bagimu. Dengan demikian, dapat dikatakan bahwa terjadinya korupsi disebabkan karena para pelakunya tidak menjalankan ajaran Islam secara keseluruhan.

Perilaku koruptif yang ada di Indonesia justru mengabaikan nilai-nilai dan ajaran yang telah ada dalam agama, pemikiran inilah yang menyebabkan munculnya sebuah asumsi bahwa pedoman agama yang dimiliki pelaku korupsi masih sangat kurang dan sangat dibutuhkan. Ketika pedoman agama dan ajaran-ajarannya bisa disampaikan dengan baik pada individu, maka kecil kemungkinan individu tersebut melakukan korupsi, hal ini bisa dilihat dari ajaran agama islam yang mengatakan agama dan al Quran sebagai pengingat kepada Allah SWT. Seseorang yang telah diberikan pedoman agama, maka ia akan selalu senantiasa mengingat Allah, dan secara otomatis akan menghindari perilaku-perilaku yang dibenciNya, salah satunya perilaku korupsi, hal tersebut dapat dikaji dalam QS AlHadiid ayat 4 yang menjelaskan bahwa Allah 
selalu mengetahui apapun yang terjadi di muka bumi ini.

Oleh karena itulah, pedoman agama ini merupakan variabel penting dalam penelitian, karena dengan adanya pedoman agama, hal tersebut akan ikut serta membantu meningkatkan kontrol dalam diri individu dan masyarakat, selain itu pedoman agama juga bisa diandalkan untuk mendongkrak kekuatan kontrol sosial untuk menanggulangi perilaku koruptif.

3. Budaya Malu (Shame Culture) dan Kaitannya dengan Permasalahan Korupsi di Indonesia

Banyak lembaga, divisi dan komunitas yang terkait selalu membicarakan tentang korupsi, namun hanya sebatas persoalannya saja, masih belum bisa dibahas secara menyeluruh terkait cara efektif untuk mengurangi tingkat perilaku koruptif yang ada di Indonesia, dan yang jauh lebih parah lagi, karena saking banyaknya pemberitaan tentang korupsi ini masyarakat menjadi terbiasa dengan suguhan dan berita tentang korupsi. Apabila hal ini terus dibiarkan, lama-kelamaan masyarakat akan menganggap permasalahan korupsi sebagai hal yang wajar, dan jika itu terjadi, hal tersebut akan menyebabkan budaya publik menjadi tidak sehat, sebenarnya dari perilaku masyarakat yang telah terbiasa akan berita korupsi saja sudah menunjukkan bahwa budaya publik ini sedang tidak sehat. Penelitian yang dilakukan oleh Alatas (1981) menunjukkan bahwa salah satu faktor penyebab individu melakukan perilaku koruptif adalah kebudayaan. Kebudayaan yang dimaksud disini adalah kebudayaan malu atau bisa disebut budaya malu (shame culture).

Penelitian yang dilakukan oleh Keller (1983) mengungkapkan bahwa budaya malu ini bisa diajarkan semenjak anak kecil untuk berperilaku sopan, mentaati aturan, dan lain sebagainya. Keller dalam penelitiannya menggunakan subjek orang jawa, dan dari hasil penelitian tersebut, tiap individu memiliki keinginan untuk memenuhi kebutuhannya, dan memilki hasrat untuk diakui, dan ketika individu melakukan suatu kesalahan, individu tersebut akan berusaha untuk menutupinya, individu tersebut akan berusaha agar apa yang ia perbuat tidak diketahui orang lain, karena bagi individu itu, ia akan merasa malu apabila kesalahan tersebut diketahui oleh publik. Inilah yang dimaksud dengan penerapan budaya malu, suatu masyarakat yang menerapkan budaya malu akan menanamkan pemikiran bahwa jika individu melakukan kesalahan atau kelalaian dalam amanah yang telah diberikan, ia akan merasa malu karena mengecewakan banyak orang. Individu akan malu karena diolok-olok masyarakat, individu akan membuat malu keluarganya, individu tersebut juga malu akan apa yang diperbuatnya.

Berdasarkan Hasil penelitian yang dilakukan oleh Keller (1983) terlihat jelas bahwa ketika seseorang melakukan kesalahan dari kelalaiannya maka yang orang tersebut akan merasa malu, kaitannya dengan perilaku koruptif adalah, ketika pelaku korupsi berada dalam lingkungan yang menerapkan shame culture maka ia akan merasa malu ketika perilaku koruptif yang dilakukaknnya diketahui oleh masyarakat, apalagi ketika diberitakan ke seluruh Indonesia, ia akan merasa malu dengan diri sendiri dan juga malu kepada keluarga serta orang yang telah memercayainya. Penelitian yang dilakukan oleh Hutagalung (2007) juga ikut berkontribusi untuk membuktikan bahwa penerapan budaya malu akan membuat pelaku korupsi merasa dirinya tidak pantas dan malu akan apa yang telah ia perbuat.

Banyaknya penelitian

yang mengungkapkan budaya malu ini sangat penting diterapkan untuk persoalan korupsi yang ada di Indonesia membuat peneliti ingin menekankan variabel ini dalam penelitian sebagai sarana untuk memperkuat kontrol sosial masyarakat agar mampu menanggulangi perilaku koruptif yang ada di Indonesia.

\section{Penyebab Munculnya Perilaku Koruptif}

Permasalahan korupsi disebabkan oleh banyak faktor, bisa karena faktor politik, ekonomi, organisasi, faktor internal dan eksternal dari dalam diri. Utari (2011) mengatakan bahwa penyebab internal seseorang melakukan korupsi adalah sifat tamak dan rakus dari diri manusia itu sendiri, pada dasarnya manusia memiliki sifat yang egois sejak kecil dengan keinginan mendapatkan apa yang diinginkan (Freud, 
2011), sehingga perilaku koruptif seseorang juga dipengaruhi faktor ego dari dalam diri yang menghasilkan perilaku tamak dan rakus meskipun telah memiliki kekayaan dan jabatan. Utari (2011) juga mengungkapkan bahwa kurangnya moral yang kuat dapat menyebabkan perilaku koruptif terjadi pada tiap individu, sehingga dapat dikatakan kurangnya moral akan menyebabkan seseorang mudah terpengaruh untuk melakukan hal- hal yang bersifat negatif, salah satunya terpengaruh untuk berperilaku koruptif.

Penyebab terjadinya korupsi diantaranya adalah:

a. Aspek Individu Pelaku korupsi Apabila dilihat dari segi si pelaku korupsi, sebabsebab dia melakukan korupsi dapat berupa dorongan dari dalam dirinya, yang dapat pula dikatakan sebagai keinginan, niat, atau kesadarannya untuk melakukan. Sebabsebab seseorang terdorong untuk melakukan korupsi antara lain sebagai berikut:

1) Sifat Tamak Manusia

Kemungkinan orang yang melakukan korupsi adalah orang yang penghasilannya sudah cukup tinggi, bahkan sudah berlebih bila dibandingkan dengan kebutuhan hidupnya.

2) Moral Yang Kurang Kuat Menghadapi Godaan

Seseorang yang moralnya tidak kuat cenderung lebih mudah untuk terdorong berbuat korupsi karena adanya godaan. Godaan terhadap seorang pegawai untuk melakukan korupsi berasal dari atasannya, teman setingkat, bawahannya, atau dari pihak luar yang dilayani.

3) Penghasilan Kurang Mencukupi Kebutuhan Hidup Yang Wajar

Apabila ternyata penghasilannya tidak dapat memenuhi kebutuhan hidupnya yang wajar, maka mau tidak mau harus mencari tambahan penghasilan untuk memenuhi kebutuhan hidupnya.

4) Kebutuhan Hidup Yang Mendesak

Kebutuhan yang mendesak seperti kebutuhan keluarga, kebutuhan untuk membayar hutang, kebutuhan untuk membayar pengobatan yang mahal, kebutuhan untuk membiayai sekolah anaknya, merupakan bentuk-bentuk dorongan seseorang yang berpenghasilan kecil untuk berbuat korupsi.

5) Gaya Hidup Konsumtif

Gaya hidup yang konsumtif di kotakota besar, mendorong seseorang untuk dapat memiliki mobil mewah, rumah mewah, pakaian yang mahal, hiburan yang mahal, dan sebagainya.

6) Malas Atau Tidak Mau Bekerja Keras

Kemungkinan lain, orang yang melakukan korupsi adalah orang yang ingin segera mendapatkan sesuatu yang banyak, tetapi malas untuk bekerja keras guna meningkatkan penghasilannya.

7) Ajaran-Ajaran Agama Kurang Diterapkan Secara Benar

Para pelaku korupsi secara umum adalah orang-orang yang beragama. Mereka memahami ajaran-ajaran agama yang dianutnya, yang melarang korupsi. Akan tetapi pada kenyataannya mereka juga melakukan korupsi

b. Aspek Organisasi

Organisasi dalam hal ini adalah organisasi dalam arti yang luas, termasuk sistem pengorganisasian lingkungan masyarakat. Organisasi yang menjadi korban korupsi atau dimana korupsi terjadi biasanya memberi andil terjadinya korupsi karena membuka peluang atau kesempatan untuk terjadinya korupsi.

c. Aspek Masyarakat Tempat Individu dan Organisasi Berada

1) Nilai-Nilai Yang berlaku Di Masyarakat Ternyata Kondusif Untuk Terjadinya Korupsi

2) Masyarakat Kurang Menyadari Bahwa Yang Paling Dirugikan Oleh Setiap Praktik

3) Masyarakat Kurang Menyadari Bahwa Masyarakat Sendiri Terlibat Dalam Setiap Praktik Korupsi

4) Masyarakat Kurang Menyadari Bahwa Pencegahan dan Pemberantasan Korupsi

5) Hanya Akan Berhasil Kalau Masyarakat Ikut Aktif Melakukannya. 
Berbagai macam upaya telah dilakukan untuk menanggulangi permasalahan korupsi, dan salah satu cara yang bisa dilakukan adalah membentuk lembaga independen yang khusus menangani permasalahan korupsi, dalam hal ini Indonesia telah membuat Komisi Pemberantasan Korupsi (KPK). Hal yang perlu diperhatikan juga dalam penanganan korupsi melalui lembaga anti korupsi adalah terkait tentang kinerja lembaga peradilan (mulai dari tingkat kepolisian, kejaksaan, pengadilan, hingga lembaga permasyarakatan). Telah diketahui bahwa pengadilan merupakan pusat utama hukum yang diwajibkan bersifat imparsial atau tidak memihak siapapun, sehingga proses yang ada terjadi secara jujur dan adil. Banyaknya kasus korupsi yang tidak terjerat hukum bisa terjadi karena kurang optimalnya kinerja dari lembaga peradilan. Reformasi birokrasi dan reformasi pelayanan publik juga merupakan salah satu cara untuk mencegah terjadinya korupsi, juga bisa dengan cara mengumumkan secara resmi biaya yang harus dikeluarkan oleh seseorang untuk mengurus beberapa hal seperti mengurus IMB, Paspor, SIM, dan lain sebagainya, hal ini dimaksudkan agar tidak terjadi praktek suap menyuap dalam dalam hal pelayanan publik.

Permasalahan korupsi di Indonesia banyak dilakukan di sektor publik, dan kebanyakan yang melakukan hal tersebut adalah orang yang telah memiliki pangkat sebagai pejabat (situmorang, 2011). Pencegahan korupsi yang dilakukan oleh pejabat pun juga telah dilakukan, dan salah satu cara yang digunakan adalah mewajibkan pejabat yang bersangkutan melaporkan dan mengumumkan jumlah kekayaan yang dimiliki baik sebelum menjabat maupun setelah menjabat, sehingga masyarkat dan lembaga anti- korupsi bisa memantau tingkat kewajaran kekayaan yang dimiliki pejabat tersebut.

Kesadaran akan bahaya dari perilaku koruptif membuat masyarakat ingin menghentikan hal tersebut, hal ini kemudian disebut public awareness atau kepedulian publik. Komisi Pemberantasan korupsi telah bekerjasama sejak beberapa tahun lalu dengan banyak perguruan tinggi dan pengajar untuk membuat sebuah modul yang berkaitan dengan pendidikan anti-korupsi, sehingga pencegahan dan pemberian pemahaman terkait dengan anti-korupsi dapat dipahami oleh seluruh masyarakat tidak hanya orang dewasa namun juga kalangan pelajar sejak duduk di sekolah dasar sekalipun. Public Awareness dapat dilakukan dengan cara melakukan kampanye dan sosialisasi tentang bahaya korupsi dan dampaknya, sehingga untuk memberdayakan masyarakat dalam hal ini menjadi lebih baik. Memberdayakan masyarakat untuk mencegah terjadinya perilaku koruptif bisa dilakukan dengan cara menyediakan sebuah sarana bagi masyarakat untuk melaporkan kasus korupsi, sehingga sebuah sistem harus dikembangkan untuk mewujudkannya agar masyarakat dengan mudah, aman dan bertanggungjawab melaporkan kasus korupsi yang diketahuinya, karena banyak masyarakat yang takut akan tuduhan pencemaran nama baik, Meskipun telah memiliki aturan UU no. 13 tahun 2006 tentang perlindungan saksi dan korban, namun tetap saja masyarakat tidak berani untuk melaporkan karena adanya rasa takut akan dituntut balik dengan tuduhan fitnah atau pencemaran nama baik, hal inilah yang perlu untuk diperhatikan juga dalam memberdayakan masyarakan untuk pencegahan perilaku koruptif.

Pencegahan lain bisa berbentuk sebuah media, karena selain dapat digunakan untuk sarana kampanye dan sosialisasi terkait antikorupsi, peran media juga bisa menjadi sarana bagi masyarakat untuk memeroleh informasi. Penggunaan electronic surveillance juga dapat digunakan, misalnya menggunakan rekaman CCTV, audio microphone,data interception, email, dan lain sebagainya, namun hal tersebut juga harus mendapatkan persetujuan dan kesepakatan bersama karena ditakutkan akan melanggar hak privacy dari pihak yang bersangkutan.

Pendukungan untuk mencegah perilaku koruptif tidak akan cukup hanya mengandalkan satu instrument yaitu undangundang pemberantasan tindak pidana korupsi, namun juga diperlukan adanya pengembangan untuk perundang-undangan dan instrumen hukum lainnya menjadi lebih optimal. Salah satu perundang-undangan yang harus ada 
untuk pemberantasan korupsi adalah tentang pencucian uang atau money laundering, dan untuk melindungi saksi dan korban tindak pidana korupsi juga perlu UU perlindungan saksi dan korban, sedangkan untuk pers juga perlu diatur agar menjadi lebih fleksibel. (Situmorang, 2011)

\section{Antara Agama dan Korupsi}

Sebagai agama mayoritas di Indonesia, Islam juga banyak menyinggung hal yang berkaitan dengan korupsi, amanah, dan tanggung jawab, salah satunya firman Allah pada QS. Al-Baqarah ayat 188 yang artinya:

Dan janganlah sebahagian kamu memakan harta sebahagian yang lain di antara kamu dengan jalan yang bathil dan (janganlab) kamu membawa (urusan) harta itu kepada bakim, supaya kamu dapat memakan sebabagian daripada harta benda orang lain itu dengan (jalan berbuat) dosa, padahal kamu mengetahui." (QS Al-Baqarah: 188).

Ayat ini berbicara tentang dosa besar penyebab ketidak adilan dan ketidak amanahan dalam ekonomi masyarakat. Dan kaum muslimin sangat dilarang melakukan; satu, perlakuan yang tidak pantas terhadap harta milik orang lain. Dua, menyuap hakim supaya dapat menguasai harta orang lain. Al-Qur'an menyebutnya dengan istilah "batil" dan "dosa". Perbuatan yang menurut akal tidak patut dan menurut syariat dosa dan haram. Ada sebagian orang demi supaya perbuatan itu tidak dianggap buruk, memberi nama "suap" dengan hadiah. Dari ayat tadi terdapat 3 pelajaran yang dapat dipetik:

a. Islam sangat mengjormati harta milik pribadi dan tidak mengizinkan menguasai harta orang lain.

b. Kepemilikan harus didapatkan dengan jalan yang halal. Menguasai harta orag lain dengan jalan tidak benar, sekalipun ada hukum hakim tetap tidak menjadi miliknya.

c. Menyuap dan disuap adalah haram, dengan nama apapun baik hadiah maupun upah.

Terdapat beberapa pilar utama yang bisa digunakan manusia untuk dijadikan landasan agar terhindar dari perilaku koruptif dan ikut serta dalam memberantasi korupsi, diantaranya adalah: a. Amanah

Islam mengartikan amanah secara estimologis berarti titipan dengan maksud agar dapat dipercaya atau dapat menjaga titipan yang telah diberikan, Amanat dapat dikatakan sebagai suatu titipan yang telah dipercayakan kepada kita untuk kita jaga, dan salah satu bentuk amanah adalah dengan tidak menyalahgunakan jabatan yang dimiliki entah untuk keuntungan pribadi, keluarga, kelompok, dan lain sebagainya, karena hal tersebut merupakan tindak korupsi secara tidak langsung.

b. Shidiq (Jujur)

Kata shidiq secara estimologi berarti jujur atau benar, umat muslim dituntut untuk selalu benar dalam artian lahir dan batin, yaitu, benar dari hati (shidiq alqolb), Salah satu bentuk kebohongan yang paling tercela adalah khianat, khianat adalah sejelek-jeleknya perilaku berbohong, kaitannya dalam hal ini, korupsi merupakan perilaku khianat yang paling besar karena telah mengkhianati amanah yang telah dipercayakan banyak masyarakat, dan jelas bahwa hal ini sangat dilarang oleh Allah SWT.

c. Adil

Adil secara estimologi berarti kesepadanan, kesetaraan, dan seimbang. Adil dalam berperilaku, berpikir, hingga menyikapi suatu permasalahan, namun dalam konsep agama islam, pengertian adil ini menjadi lebih luas, bisa berarti keadaan sesuatu yang seimbang, umat muslim dituntut juga untuk berperilaku adil, dalam artian tidak merugikan orang lain. Allah SWT menegaskan bahwa perilaku adil mendekatkan diri kita kepada taqwa, sebaliknya, perilaku tidak adil akan mendatangkan keburukan bagi kita, tidak hanya menjadi individu yang tercela, namun juga menjauhkan diri kita dari Allah SWT.

d. Taqwa

Taqwa berarti penjagaan diri dari hal-hal tidak baik, menjaga diri dari kejahatan, berhati-hati dalam berperilaku, dan menghormati serta menepati apa-apa saja yang telah menjadi tanggung jawabnya. 
Khodijah: Agama dan Budaya Malu Sebagai...

Berperilaku Taqwa membantu kita mendekatkan diri pada Allah, dan meningkatkan keimanan kita, dalam artian kita akan menghindarkan diri dari perbuatan-perbuatan tercela yang bertentangan dengan taqwa.

\section{Budaya Malu di Indonesia}

Rasa malu hampir serupa dengan rasa bersalah, jika rasabersalah lebih mengarah pada perasaan bersalah terkait dengan apa yang telah dilakukan, sedangkan rasa malu lebih kearah perasaan atau emosi yang muncul karena perilaku yang dilakukannya membuat orang lain mencemooh, menjauhi, bahkan mempermalukan dirinya sendiri, bahkan di kasus yang ekstrim hal tersebut juga berdampak pada orang yang ada disekitarnya, perasaan malu membuat orang yang bersangkutan merasa tidak nyaman dan merasa diasingkan, namun dengan adanya hal tersebut menjadi sebuah asumsi bahwa jika malu dijadikan sebuah budaya, hal tersebut akan membatasi seseorang agar tidak melakukan sesuatu hal yang membuat dirinya sendiri menanggung rasa malu (Schirrmacher, 2013).

Hal ini menunjukkan bahwa budaya malu yang ada di Indonesia belum sepenuhnya aktif memengaruhi setiap perilaku manusia, sehingga dapat dikatakan budaya malu yang ada di Indonesia belum sepenuhnya berfungsi.Penelitian tentang budaya malu di Indonesia masih sangat seditikit, hal ini juga menimbulkan asumsi bahwa kurangnya perhatian pada budaya malu untuk mencegah perilaku koruptif masih belum di optimalkan. Kesadaran akan tanggung jawab dan konsekuensi juga menjadi salah satu hal yang penting dalam mencegah perilaku koruptif (kosassih, 2018),

Budaya malu di Indonesia sangatlah minim, banyaknya kasus korupsi yang terjadi dan diberitakan media massa tidak membuat pelaku merasa bersalah, ada yang masih santai, ada yang masih bisa tersenyum, bahkan kasus yang baru saja terjadi terkait dengan korupsi yang dilakukan oleh setya novanto yang justru mencari alasan, dan mencari cara untuk melindungi diri sendiri. Hal ini justru bertentangan dengan budaya malu, ini juga yang menjadi bukti bahwa Indonesia masih kurang mengoptimalkan budaya malu, padahal budaya malu ini memiliki peranan penting untuk membatasi perilaku koruptif seseorang.

Penelitian yang dilakukan oleh Lusiana (2010) menunjukkan perbedaan budaya malu yang ada di Jepang dengan Indonesia, dalam penelitian tersebut menyebutkan bahwa, perasaan atau emosi malu yang dimiliki masyarakat jepang terjadi dalam konteks sosial, dalam artian selalu melibatkan orang lain. Masyarakat jepang menganggap dia berada dalam sebuah kelompok diamana ia adalah anggotanya dan memiliki keterikatan emosi dengan anggota-anggota yang lain, sehingga hal ini menyebabkan tiap anggota ikut serta mempengaruhi anggota lain, hal ini yang menjadi satu acuan perasaan atau emosi malu masyarakat jepang muncul, namun disisi lain juga seseorang yang memiliki latar belakang budaya jepang juga akan memunculkan perasaan malu apabila seseorang mengevaluasi dirinya. Disinilah akhirnya terlihat bahwa pengaruh kelompok sangat besar bagi tiap individu untuk membentuk sebuah perilaku.

Sedikitnya penelitian tentang budaya malu di Indonesia ini juga menjadi sebuah acuan bahwa masyarakat Indonesia belum sepenuhnya memahami apa itu budaya malu, dan belum benar-benar bisa untuk menerapkan kebudayaan tersebut. Penelitian yang selama ini ada tentang kebudayaan malu pernah dilakukan oleh Schirrmacher (2013) dalam penelitiannya juga mengatakan bahwa budaya malu ikut serta dalam memengaruhi perilaku manusia dan membatasi perbuatanperbuatan yang menuju kearah negatif. Penelitian oleh Hamzon situmorang pada tahun 2008 juga mengungkapkan budaya malu di jepang berhasil menekan tingkat korupsi yang terjadi dan memberi dampak jera bagi para pelakunya. Bahkan para pejabat yang melakukan korupsi bersedia dihukum dan meninggalkan jabatannya serta mengaukui kesalahan dihadapan publik atau media.

Kekuatan budaya malu telah banyak dibuktikan dari beberapa penelitian, dan menunjukkan bahwa hingga saat ini negara Jepang memiliki tingkat budaya malu yang sangat tinggi, yang membuat hal ini 
memperkuat masyarakatnya untuk tidak melakukan korupsi, dan tetap menjalankan amanah serta tanggung jawab yang telah diberikan, meskipun adakalanya beberapa pejabat korupsi, ia akan menerima kesalahan dari apa yang telah diperbuatnya, darisinilah terlihat bahwa budaya malu juga ikut serta mengontrol manusia agar tidak melakukan perilaku koruptif.

\section{Kekuatan Agama sebagai Pengontrol Perilaku Manusia}

Sebagai suatu agama, Islam mengatur segala macam roda kehidupan manusia, mulai dari ekonomi, sosial, politik, hingga spiritualitas dan berbagai macam aspek kehidupan lainnya dengan berlandaskan oleh Al-Quran dan Al- Hadits yang mengontrol perilaku dan norma manusia, demikianlah juga, Allah SWT menciptakan manusia dengan perilaku yang berbeda-beda, suku dan ras yang berbeda, dan karakteristik yang berbeda juga, semua hal tersebut ada agar manusia bisa saling mengenal dan memahami. Allah SWT berfirman dalam QS. Al-Hujurat: 13 yang artinya:

"wahai manusia, sesunggubnya kami menciptakan kamu dari seorang laki-laki dan perempuan dan menjadikanmu berbangsabangsa, bersuku-suku, supaya kamu saling kenal mengenal. Sesunggubnya orang yang paling mulia diantara Kamu disisi Allah ialah orang yang paling taqwa diantara kamu. Sesunggubnya Allah maha mengetabui lagi maha mengenal" (QS. Al- Hujurat: 13).

Manusia diciptakan sebagai makhluk yang paling mulia, dan sebagaimana yang telah dijelaskan dalam Al-Qur'an, manusia diciptakan dengan kondisi yang paling baik dan sempurna, karena telah dianugerahkan akal yang tidak dimiliki oleh makhluk lain. Manusia diciptakan dengan adanya akal dan hawa nafsu sehingga dalam berperilaku, manusia itu sendirilah yang mengontrol perilaku tersebut, namun dalam menjalani kehidupan, tidak sedikit manusia yang gagal dalam mengendalikan akal dan hawa nafsunya, yang kemudian mengarahkan manusia kearah perbuatan dosa. Meskipun manusia terlahir dalam keadaan yang fitrah, hal tersebut akan melenceng dan sia-sia apabila manusia tersebut mengikuti hawa nafsunya untuk berbuat maksiat dan dosa.

Pengamalan agama menjadi penting apabila diterapkan sebagai pengontrol sosial untuk menanggulangi perilaku koruptif yang ada di Indonesia. Seseorang yang benar- benar memiliki pedoman agama dan iman yang kuatakan memiliki kepercayaan penuh akan apa yang telah diajarkan Allah dan Rasul kepadanya dan tidak akan mudah terpengaruh dengan hal-hal yang membuatnya melakukan tindakan korupsi. Salah satu unsur penting dalam terbentuknya kontrol sosial adalah adanya involvement atau pengaruh atau kerjasama dari masyarakat untuk menciptakan adanya kontrol sosial (Hirschi, 1969). Budaya malu diperlukan untuk mengontrol perilaku koruptif manusia dengan cara memberikan efek jera dan rasa malu pada pelaku, namun untuk mewujudkan hal ini perlu adanya kerjasama dengan masyarakat untuk penerapannya sehingga budaya malu ini bisa menjadi sebuah kontrol sosial dalam menanggulangi perilaku koruptif.

Masyarakat Indonesia saat ini telah melakukan beberapa hal untuk menanggulangi permasalahan korupsi, seperti membuat buku anti korupsi, mengunggah gambar-gambar "koruptor adalah penjahat", men-judge bahwa koruptor adalah tikus rakus berdasi, poster-poster, dan lain sebagainya, namun seakan hal tersebut belum memberikan efek malu atau jera bagi para pelaku korupsi, dan masih banyak para koruptor yang masih tidak merasa bersalah atau bahkan masih bisa tersenyum ketika sudah ketahuan bersalah. Internalisasi perilaku malu berbuat korupsi dan melawan hukum dapat diwujudkan dari keteladanan para pemimpin. Bila pemimpin itu mewariskan kebajikan dan taat pada hukum, niscaya masyarakat juga akan meneladaninya.

Kedua, budaya malu dapat disosialisasikan di ranah keluarga. Peran orang tua sangat menentukan kualitas karakter dan martabat kepribadian anak-anaknya. Berbuat kebajikan untuk peduli kepada sesama dan larangan mengambil yang bukan haknya termasuk tindakan bermoral yang patut dibudayakan di lingkungan keluarga. Keluarga merupakan benteng utama menanam benih 
Khodijah: Agama dan Budaya Malu Sebagai...

moral bagi pembentukan nilai-nilai kepribadian.

Ketiga, melestarikan budaya malu hendaknya diimplementasikan di lembaga pendidikan sekolah. Menurut Emile Durkheim, sekolah mempunyai tugas dan fungsi untuk menanamkan nilai-nilai yang bermanfaat guna mempertahankan sistem sosial. Sebagai salah satu agen sosialisasi, sekolah memiliki peran sentral, yaitu mengubah dan memproduksi berbagai sistem nilai budaya dari satu generasi ke generasi berikutnya. Kebudayaan yang diproduksi bisa berupa ilmu pengetahuan, kecakapan, nilai, dan sikap.

Keempat, penegakan hukum merupakan salah satu instrumen penting mewujudkan budaya malu di kehidupan masyarakat. Kerja kolektif dan sinergi antarlembaga sosial: politik, hukum, dan aparat kepolisian dalam memberantas korupsi serta-merta tak lepas dari pengawalan publik. Terakhir, fungsi media massa sejatinya menjadi penompang nilai-nilai budaya bangsa. Melalui media diupayakan kerja kreatif berupa kampanye menggalakkan antikorupsi bisa diimplikasikan secara permanen. Sayangnya, iklan-iklan komersial tak mendidik, seperti iklan rokok yang nyaris membunuh jutaan orang, lebih sering menyergap ruang publik.

Pengamalan agama dan budaya malu, menjadi salah satu variabel penting dalam terciptanya kontrol sosial yang optimal untuk menanggulangi permasalahan korupsi yang ada di Indonesia, hal ini akan menjadi lebih baik ketika menggabungkan dua variabel ini, dimana budaya malu yang membuat seseorang menyadari akan tanggung jawab jabatannya dan takut akan merasakan perasaan malu ketika melakukan korupsi yang kemudian membuat seseorang tidak akan melakukan korupsi dan hal ini diperkuat dengan adanya pedoman agama sebagai pengamalan hidup yang menjadikan seseorang beriman kepada Allah SWT untuk tidak melakukan perbuatan dosa.

\section{PENUTUP}

Memberantas korupsi adalah hal yang harus dilakukan, apalagi kita sebagai masyarakat Indonesia, tentunya kita tidak ingin bahwa negara kita dicap negara dengan tingkat koruptor yang tinggi, namun untuk menanggulangi permasalahan korupsi dibutuhkan usaha keras dan effort yang besar pula agar tercipta kerjasama untuk terus memberantasi dan membentengi diri dari perilaku koruptif. Penelitian ini dilakukan guna untuk memberikan gambaran kepada masyarakat bahwa budaya malu dan agama dapat dijadikan suatu variabel untuk meningkatkan kontrol sosial dalam menanggulangi perilaku koruptif yang ada di Indonesia.

Kurang optimalnya budaya malu dan kurang adanya penelitian tentang budaya malu untuk menanggulangi permasalahan korupsi ini semoga menjadi inspirasi bagi penelitian selanjutnya untuk lebih memerhatikan hal tersebut dan menjadikannya sebagai sarana untuk meningkatkan kontrol sosial masyarakat Indonesia, selain itu pedoman agama saat ini hanya dianggap sebagai status "agama" saja, masih belum banyak masyarakat yang menerapkan makna dan ajaran dari Al-Quran dan Al-Hadits, semoga untuk kedepannya Indonesia mampu untuk menerapkan pelajaran dari sisi agama dan spiritualitas yang kemudian bisa digunakan untuk menguatkan diri agar tidak terjerumus pada perilaku koruptif.

Menerapkan budaya malu dengan menguatkan pedoman agama untuk menanggulangi permasalahan korupsi ini juga pernah disinggung oleh Quraish Shihab (2017) melalui pesannya kepada masyarakat Indonesia untuk berjihad melawan korupsi:

"saudaraku, mari kita berjihad melawan korupsi, jihad adalah mencurabken segala kemampuan bingga tujuan yang diharapkan tercapai atau sampai modal yang dimiliki berakhir, di jaman pembangunan saat ini, kita juga perlu berjibad melawan korupsi, yakni, berjuang sekuat kemampuan kita untuk memberantasnya sampai titik nafas terakbir, jïka kita berbasil ,kita bersyukur karena korupsi terberantas, jika belum berbasil kita juga bersyukur karena kita akan mendapatkan ganjaran dari Allah SWT. Berjibad disesuaikan dengan kemampuan masing-masing, yang dapat menulis, tulislah menyangkut korupsi dan keburukannya, yang 
mempunyai pengetahuan untuk menggambarkan keburukannya, sampaikanlah pengetabuan itu, yang mampu bercakap, bercakaplah, nasehatilah, agar kita bersama-sama mampu memberantasnya, dan bagi yang tidak mampu apa-apa, maka dia bisa berdoa kepada Allah, berdoalah semoga negara ini dipelibara-Nya dari para koruptor, dan semoga para koruptor segera sadar akan perbuatannya (insyaf) atau Allab memberikan balasan kepada mereka, semoga jihad kita berhasil untuk melawan korupsi"

Pesan yang singkat namun memberikan pemahaman yang meyakinkan kita bahwa perlu adanya rasa malu untuk dijadikan sebuah budaya yang bisa memberikan efek jera dan rasa dipermalukan bagi pelaku korupsi, tidak hanya itu, meningkatkan keimanan juga hal yang penting bagi kita, menjadikan agama sebagai pedoman untuk berjihad melawan korupsi menjadi tambahan yang sempurna untuk budaya malu, karena kedua hal tersebut saling berkaitan satu sama lain untuk menguatkan nilai anti-korupsi yang kemudian diharapkan menjadi sarana kontrol sosial dalam menanggulangi perilaku koruptif yang ada di Indonesia.

\section{Simpulan}

Perilaku koruptif merupakan perilaku negatif yang menunjukkan penyalahgunaan tindakan dengan cara mempergunakan materi yang telah dipercayakan oleh masyarakat pada dirinya namun digunakan untuk keperluan pribadi. Prilaku ini adalah prilaku menyimpang dimana individu menyalahgunakan kekuasaan, kewenangan, dan jabatan yang telah dipercayakan untuk keperluan pribadi. Perilaku koruptif yang terjadi adalah perilaku yang menyimpang dari tatanan norma masyarakat sosial. Menurut Hirschi (1969) perilaku menyimpang yang terjadi pada individu disebabkan adanya dorongan dari dalam individu itu sendiri karena Hirschi mempercayai bahwa pada dasarnya tiap orang tidak bisa mentaati aturan yang berlaku. Oleh karena itulah dibutuhkan sebuah kontrol yang bisa mengendalikan perilaku-perilaku menyimpang dalam hal ini kaitannya dengan korupsi. kontrol tersebut adalah kontrol sosial, Indonesia masih lemah terkait denga kontrol sosial untuk permasalahan korupsi, sehingga tidak heran apabila perilaku koruptif yang ada di Indonesia masih ada hingga sekarang.

Agama merupakan pedoman hidup bagi semua manusia, meskipun di muka bumi ini terdapat banyak agama namun sebenarnya tujuan dari setiap agama adalah sama, yaitu menciptakan kedamaian dan kebahagiaan pada setiap makhluk hidup, begitu pula dengan agama Islam yang merupakan agama yang memberikan segala solusi untuk kemaslahatan dunia maupun akhirat termasuk juga mengajarkan dan mengontrol perilaku manusia. Islam telah mengajarkan bagi seluruh pemeluk agama Islam untuk mampu mengontrol diri dari godaan hawa nafsu untuk mencegah seseorang terjerumus ke arah perbuatan yang negatif, mencegah perilaku serakah, dan menghindarkan diri dari perbuatan dosa. Orang yang beriman akan senantiasa mengikuti dan mengamalkan ajaran syariat Islam sebagai pedoman hidup dan menjadikannya sebagai pengontrol bagi perilaku manusia. Pedoman dan pengamalan agama menjadi penting apabila diterapkan sebagai pengontrol sosial untuk menanggulangi perilaku koruptif yang ada di Indonesia. Seseorang yang benar-benar memiliki iman dan kepercayaan yang kuat yang telah diajarkan Allah dan Rasul kepadanya tidak akan mudah terpengaruh dengan hal-hal yang membuatnya melakukan tindakan korupsi. adanya pedoman agama menjadikan seseorang memiliki bekal dalam artian akal pikiran bahwa perbuatan atau perilaku koruptif merupakan hal yang bertentangan dengan ajaran agama Islam serta merupakan perbuatan yang harus dihindari.

Budaya malu dan pengamalan agama yang kuat dapat digunakan untuk menjadi kontrol sosial menanggulangi korupsi memang belum sepenuhnya berjalan dengan baik di Indonesia, namun jika kedua hal ini berhasil dilakukan dapat diyakini bahwa akan mengurangi tingkat perilaku koruptif masyarakat Indonesia, oleh karena itulah penting untuk menanamkan nilai anti korupsi dan terus membangun budaya malu ini. Jika dikaitkan dengan agama kita harus berjihad melawan berbagai bentuk korupsi dan dibutuhkan adanya kerjasama, komitmen dan keterlibatan antara pihak yang terkait dengan masyarakat, begitu pula dengan budaya malu apabila rasa malu dijadikan sebuah budaya maka harus ada kerjasama dan konsistensi atau 
Khodijah: Agama dan Budaya Malu Sebagai...

komitmen untuk terus melakukannya agar hal ini menjadi budaya yang dihormati oleh seluruh warga. Keterlibatan antara pemerintah dan masyarakat menjadi poin penting untuk terus mempertahankan budaya malu ini sebagai kontrol sosial untuk mencegah prilaku koruptif.

\section{DAFTAR PUSTAKA}

Alatas, S. H. (1981). Sosiologi korupsi sebuah penjajahan dengan data kontemporer. Jakarta: LP3ES.

Diansyah, F. dkk. (2011). Penguatan Pemberantasan Korupsi Melalui Fungsi Koordinasi dan Supervisi Komisi Pemberantasan Korupsi. Jakarta : Indonesia Corruption Watch. Djaja, Ermansjah. 2008. Memberantas Korupsi Bersama KPK. Jakarta: Sinar Grafika.

Hariyanto, Mushin (2004). Korupsi dalam perspektif islam. Yogyakarta: Universitas Muhammadiyah

Herdiansyah, H. (2015). Metodologi penelitian kualitatif untuk ilmu psikologi. Jakarta: Salemba Humanika.

Hidayat, B. (2014). Psikologi Islam. Riau : Universitas Islam Negeri Sultan Syarif Kasim. Hirschi, T. (1969). Causes of delinquency. Berkeley: University of California Press.

Iqbal, C. I. (2014). Budaya Malu dalam Masyarakat Jepang dan Bugis-Makassar. Makassar : Universitas Hasanuddin.

Kartono, Kartini. 2005. Patologi Sosial, Jakarta: Raja Grafindo Persada. Keller, F. S. (1995). Principles of psychology. America : Andesite Press.

Klitgaard, Robert. 2001. Membasmi Korupsi. Jakarta: Yayasan Obor Indonesia.

Komisi Pemberantasan Korupsi. 2006. Memahami untuk Membasmi. Jakarta: Diterbitkan oleh Komisi Pemberantasan Korupsi

Leaman James (2009). Religion, Spirituality, Corruption and Development: causal links and Relationships. New York : Oxford University.
Lubis, Bahril Hidayat. (2002). Dialektika Psikologi dan Pandangan Islam. Pekanbaru: UNRI Press.

Majelis Ulama Indonesia (2000). Risywah (suap), Ghulul (korupsi), dan hadiah kepada pejabat. Jakarta : Majelis Ulama Indonesia

Marzuki (2001). Pudarnya budaya malu. Yogyakarta: Universitas Negeri Yogyakarta. Poerwandari, E.K. (1998)., Pendekatan Kualitatif dalam Penelitian. Jakarta: Lembaga pengembangan sarana pengukuran dan pendidikan psikologi (LPSP3) Fakultas Psikologi Universitas Indonesia.

Puspito, Nanang T. Et al (ed). 2011. Pendidikan Antikorupsi untuk Perguruan Tinggi.Jakarta: diterbitkan oleh Kementrian Pendidikan dan Kebudayaan RI Direktorat Jenderal Pendidikan Tinggi Bagian Hukum Kepegawaian

Rosikah, C. D. \& Listianingsih, D. M. (2016). Pendidikan Antikorupsi. Jakarta : Sinar Grafika

Schirrmacher, Thomas (2013). Culture of Shame / Culture of Guilt (6thed). Bonn : Culture and Science publ.

Schutte, S. A.(2007). The fight against corruption in Indonesia. Cologne : GESIS Leibniz Institute.

Skinner, B. F. (1953). Science and Human Behavior. New York : The Free Press.

Syarif, Z. (2010). Upaya Islam dalam Membendung Budaya Korupsi. Pamekasan : KARSA.

Tim Penulis Pendidikan Anti Korupsi. (2011). Pendidikan Anti Korupsi untuk Perguruan Tinggi. Jakarta : Kementrian Pendidikan dan kebudayaan RI. Direktorat Jendral Pendidikan Tinggi.

Wijayanto dan Ridwan Zachrie. 2009. Korupsi Mengorupsi Indonesia: Sebab, Akibat, dan Prospek Pemberantasan. Jakarta: Gramedia Pustaka Utama.

Bahri, S. (2015). Korupsi dalam kajian hukum islam. Aceh : Universitas Syiah Kuala (Kanun Jurnal Ilmu Hukum) 
Cohen \& Vila (1996). Self-Control and SocialControl: an Exposition of the Gottfredson- Hirschi/Sampson-Laub Debate. Retrieved from https://www.researchgate.net/profile/Br yan_Vila/publication/228106740_Selfcontrol_and_Social_Control_An_Exposit ion_of_the_Gottfredson_-

_Hirschi_Sampson_-

_Laub_Debate/links/0fcfd4ff3bbe9cbe5

9000000/Self-control-and-Social-Control-

An-Exposition-of-the-Gottfredson-

Hirschi-Sampson-Laub-Debate.pdf.

Cresswell, I. (1998). Research Design: Qualitative 8 Quantitative Approaclics. Thousand Oaks,, CA: Sage Publications.

Fazzan (2015). Korupsi di Indonesia dalam Perspektif Hukum Pidana Islam. Kuala Lumpur : University of Malaya

Fakhrullah, Zudan Arif. "Akuntabilitas Kebijakan dan Pembudayaan Perilaku Antikorupsi”.

Jurnal Perspektif, Volume XVI No. 2. Edisi April 2011.

Freud, S. (2011). A General Introduction to Psychoanalisis. Retrieved from http://www.gutenberg.org/ebooks/3821 $9 ? \mathrm{msg}=$ welcome_stranger

Gintis, Herbert, dkk. (2015). Zoon Politikon the evolutionary origins of human political system. Retrieved from http://www.umass.edu/preferen/gintis/ hypercognition.pdf

Hutagalang, M. P. (2007). Budaya malu, budaya salah, dan budaya hukum. Jakarta : Jurnal Hukum \& Pembangunan.

Keeler, W. (1986). Shame and Stage Fright in Java". ETHOS, 11-3. "Society for Psycological Antropology", KOMPAS.

Ko Kilkon \& Moon, S. (2013). The relationship between religion and corruption:Are the proposed causal links empirically valid?. Seoul : The Korean Association for Public Administration.

Lebra, T. S. (1983). Shame and Guilt: a Psychocultural View of the Japanese Self. Hoboken : Blackwell Publishing on behalf of the American Anthropoligical Association.

Lusiana, Y. (2010). Konsep Malu dan Bersalah Orang Jepang: Sebuah Tinjauan Psikologi Komunikasi Berperspektif Budaya. Purwokerto: Universitas Jendral Soedirman (Acta diurnal).

Newman, W.L., (1997). Social Research Methods ; Qualitative and Quantitative Approaches (3th ed): Printed in the United States of America.

Peguero, dkk. (2011). Social Control Theory and school misbehavior: Examining the Role of Race and Ethnicity. Retrieved from http://www.sagepub.com 